\title{
Bogustaw Cudowski*
}

\section{Problemy kwalifikacji prawnej umowy o dzieło}

\section{Uwagi wprowadzające}

roblematyka zatrudnienia cywilnoprawnego nabrała niezwykle dużej wagi po zmianie ustroju społeczno-gospodarczego. Stało się tak przede wszystkim dlatego, że pracodawcy dążąc do zminimalizowania kosztów coraz częściej zawierali umowy cywilnoprawne zamiast umów o pracę. Problem powyższy został zauważony i uwzględniony przez Komisję Kodyfikacyjną w projekcie nowego kodeksu pracy. Przewidziano w nim podstawowe elementy ochrony (np. właściwość sądów pracy, zakaz dyskryminacji, zaliczanie stażu pracy do zatrudnienia pracowniczego czy ochronę kobiet w ciąży) dla zatrudnienia o charakterze niepracowniczym. Jak wiadomo w ostatnim czasie problem ten ciaggle narasta, co wywołuje burzliwą dyskusję publiczną dotyczącą w szczególności sposobów przeciwdziałania temu zjawisku.

Nie ulega jednak wątpliwości, że nie da się całkowicie zlikwidować zawierania stosunków zatrudnienia o charakterze cywilnoprawnym. W związku z tym należy zauważyć, że już od dawna na gruncie obecnie obowiązujących przepisów pojawiają się liczne problemy dotyczące kwalifikacji poszczególnych umów cywilnoprawnych. Szczególnie istotnym i często występującym w praktyce problemem jest rozróżnienie umów cywilnych od umowy o pracę. Okazuje się jednak, że problemy o podstawowym charakterze dotyczą także kwalifikacji prawnej poszczególnych umów cywilnoprawnych. Chyba największe trudności i problemy występują w zakresie odróżnienia umowy o dzieło od umowy zlecenia i umowy o świadczenie usług, do których stosuje się odpowiednio przepisy o zleceniu.

* Prof. zw. dr hab., kierownik Katedry Prawa Pracy, Wydział Prawa Uniwersytetu w Białymstoku. Sędzia Sądu Najwyższego. 
Problem powyższy jest niezwykle istotny nie tylko dla teorii. W praktyce przesądza on bowiem nie tylko o wyborze stosowania przepisów kodeksu cywilnego, ale ma zasadnicze znaczenie dla ustalenia obowiąz$\mathrm{ku}$ ubezpieczenia społecznego. W literaturze prawa pracy problematyka zatrudnienia niepracowniczego, jak i nietypowego, była podejmowana w ostatnich latach dosyć często ${ }^{1}$. Jednak nie została w niej wyjaśniona kwestia odróżnienia umowy o dzieło od umowy zlecenia. Także w doktrynie prawa cywilnego od dawna już prezentowane były bardzo różne poglądy.

Mogłoby się wydawać, że ze względu na długi okres obowiązywania w zasadzie niemal identycznej regulacji prawnej dotyczącej określenia definicji poszczególnych umów cywilnoprawnych, problem ich rozróżnienia powinien już dawno zostać wyjaśniony. Jednak sytuacja obecna jest całkowicie odmienna. Już tylko bowiem na podstawie pobieżnego przeglądu poglądów doktryny i orzecznictwa sądowego można bez trudu zauważyć występowanie zupełnie podstawowych problemów i niejasności. Stąd uzasadnione wydaje się podjęcie problematyki odróżnienia umowy o dzieło od umowy zlecenia. Ponadto należy w tym miejscu zauważyć, że w zakresie ubezpieczeń społecznych umowa o dzieło zawsze była traktowana w wyjątkowy sposób z uwagi na brak obowiązku opłacania składek². Także ostatnie zmiany przepisów ubezpieczeniowych, mające na celu ograniczenie umów cywilnoprawnych, nie obejmują umów o dzieło. Mogłoby się także wydawać, że problemy związane z zawieraniem umów o dzieło są marginalne, gdyż osoby często je zawierające będą podlegały ubezpieczeniu społecznemu twórców lub osób prowadzących działalność gospodarczą. Jednak, jak pokazuje praktyka, liczba sporów związanych $\mathrm{z}$ obowiązkiem opłacania składek na ubezpieczenia społeczne jest znaczna, co potwierdza duża liczba orzeczeń Sądów Apelacyjnych i Sądu Najwyższego. Wyjaśnienie wskazanego wyżej problemu jest niezwykle istotne dla podmiotów zawierających umowy cywilnoprawne. W szczególności dotyczy to płatnika składek, który może ponieść odpowiedzialność za błędne zakwalifikowanie umowy zlecenia jako umowy o dzieło. Ponadto nadużywanie umów o dzieło w celu uniknięcia płacenia składek jest postrzegane jako jeden z podstawowych problemów rynku pracy ${ }^{3}$.

Na podstawie powyższego można więc stwierdzić, że w chwili obecnej istnieje uzasadniona potrzeba bliższego przyjrzenia się problemowi kwalifikacji i odróżnienia umowy o dzieło od pozostałych umów cywilnoprawnych o świadczenie usług 4 .

${ }^{1}$ Zob. np. M. Gersdof, Umowa o prace. Umowa o dzieło. Umowa zlecenia, Warszawa 1993 czy A. Musiała, Zatrudnienie niepracownicze, Difin, Warszawa 2011.

2 Poza przypadkami zawierania umów o dzieło z własnym pracodawcą.

3 Tak M. Gersdorf, Prawo zatrudnienia, Warszawa 2013, s. 91.

${ }^{4}$ Mając na uwadze tematykę księgi należy zaznaczyć, że autor niniejszego opracowania nie wychodzi z założenia, iż przyszłość prawa pracy należy do umowy o dzieło czy innych umów cywilnoprawnych. 


\section{Cechy charakterystyczne umowy o dzieło}

Definicja umowy o dzieło jest określona w art. 627 k.c. Przepis ten stanowi, że przez umowę o dzieło przyjmujący zamówienie zobowiązuje się do wykonania oznaczonego dzieła, a zamawiający do zapłaty wynagrodzenia. Należy w tym miejscu zauważyć, że art. 478 k.z. definiował umowę o dzieło w identyczny sposób. Poglądy dotyczące pojęcia tej umowy sformułowane na podstawie tego przepisu zachowały więc aktualność w obecnym stanie prawnym.

Opierając się na definicji kodeksowej powszechnie przyjmuje się, że podstawowym elementem różniącym umowę o dzieło od innych umów o świadczenie usług jest osiągnięcie umówionego rezultatu. Umowy o świadczenie usług (zlecenia) są bowiem umowami starannego działania. Jednak okazuje się, że zarówno w doktrynie, jak i orzecznictwie kwalifikacja prawna rezultatu umowy o dzieło stanowi przedmiot zasadniczych niejasności i kontrowersji.

Przed przystąpieniem do szczegółowych rozważań w tej kwestii trzeba zauważyć, że zarówno w doktrynie, jak i orzecznictwie sądowym formułowane są dodatkowe elementy konstrukcyjne pojęcia umowy o dzieło. Sytuacja taka nie może dziwić, gdyż definicja ustawowa jest niezmiernie lakoniczna ${ }^{5}$. Można więc zakładać, że ustawodawca pozostawił dookreślenie cech umowy o dzieło właśnie doktrynie i orzecznictwu sądowemu.

Wyjściowo należy stwierdzić, że powszechnie akceptowany jest podział rezultatów umowy o dzieło na rezultaty materialne i niematerialne. Ten zasadniczy podział jest oczywisty jedynie z pozoru. Rezultat umowy o dzieło może oprócz wytworzenia rzeczy polegać także np. na przerobieniu rzeczy czy umyciu szyb lub przeładowaniu towaru. W odniesieniu do wyżej wymienionych przykładów przyjmowano, że pomimo braku ucieleśnionego materialnie rezultatu nie ma przeszkód, by taki rodzaj wyników pracy i umiejętności ludzkich zaliczyć do rezultatów mogących być przedmiotem umowy o dzieło ${ }^{6}$. Wydaje się, że w przeciwnym kierunku idzie orzecznictwo sądowe. W wyroku z dnia 28 marca 2000 r., II UKN 386/997, Sąd Najwyższy stwierdzit, że czynności polegające na przemieszczaniu i układaniu w stosy drewna, za pomocą własnego środka transportu, bez nadzoru ze strony zamawiającego i bez wymagania osobistego świadczenia pracy, nie mają charakteru czynności przynoszących konkretny, indywidualny rezultat materialny i są realizowane $\mathrm{w}$ ramach

${ }^{5}$ W niektórych orzeczeniach Sądu Najwyższego twierdzi się nawet, że kodeks cywilny nie definiuje w art. 627 dzieła (np. w wyroku z dnia 18 czerwca 2003 r., II CKN 269/01, OSNC 2004, nr 9, poz. 142) natomiast w innych stwierdza się, że w art. 627 k.c. zdefiniowano umowę o dzieło (np. w wyroku z dnia 4 czerwca 2014 r., II UK 548/13, LEX nr 1496287).

${ }^{6}$ W. Siuda, Istota i zakres umowy o dzieło, Poznań 1964, s. 15.

7 OSNP 2001, nr 16, poz. 522. 
starannego działania, a więc $\mathrm{w}$ ramach umowy zlecenia, a nie umowy o dzieło. Można w tym miejscu postawić pytanie, czym są ułożone stosy drewna lub inaczej, dlaczego nie można ich traktować jako rezultatu materialnego zawartej umowy. Ponadto powszechnie przyjmuje się, że wykonanie dzieła nie wymaga nadzoru zamawiającego, czy ścisłego określenia sposobu wykonania dzieła. W wyroku z dnia 26 marca 2013 r., II UK 201/12 ${ }^{8}$, Sąd Najwyższy przyjął, że dziełem nie jest odpeszczanie śliwek. Podobnie co do przedmiotu umowy wypowiadają się Sądy Apelacyjne rozstrzygając, że nie może stanowić przedmiotu umowy o dzieło oczyszczenie terenu z samosiewów ${ }^{9}$, staranne załadowanie samochodu ciężarowego $^{10}$, porządkowanie (koszenie) trawników ${ }^{11}$, czy przycięcie krzewów do kształtu kuli i stożka ${ }^{12}$. W odróżnieniu od przypadków, w których można mieć wątpliwości w omawianym zakresie ${ }^{13}$ czy oczywistych ${ }^{14}$, wskazane wyżej przykłady przedmiotu umowy mogą moim zdaniem być kwalifikowane jako dopuszczalny przedmiot umowy o dzieło. Należy jednak podkreślić, że w rozstrzyganych sprawach sądy przywoływały także innego rodzaju argumenty, jak np. powtarzalność czynności, stałe wynagrodzenie, brak odrębnego bytu dzieła czy brak myśli twórczej, o czym będzie mowa w dalszych wywodach.

Jeszcze większe kontrowersje występują w kwestii dzieła o charakterze niematerialnym. Typowym przykładem przedmiotu umowy o charakterze niematerialnym jest koncert, wystawienie sztuki teatralnej, recytacja czy wreszcie wykład akademicki. Punktem wyjściowym jest problem określoności przedmiotu zamówionego dzieła. Wydaje się, że w tej kwestii również panuje zgodność poglądów, co do tego, że rezultat dzieła powinien być określony przez strony oraz musi on być obiektywnie osiągalny, pewny i samoistny. Jednak i w tej kwestii wyrażane były już od dawna sprzeczne poglądy. Twierdzono więc, że wymóg samoistności dzieła jest zachowany, gdy dzieło (np. nauczanie zawodu, koncert, przedstawienie teatralne) na skutek swoich walorów artystycznych utrwala się w pamięci ludzkiej i w tej postaci zostaje zachowane ${ }^{15}$. Problem ten był podobnie

${ }^{8}$ LEX nr 1341964.

9 Wyrok Sądu Apelacyjnego w Szczecinie z dnia 24 maja 2013 r., III AUa 22/13, LEX nr 1416294.

10 Wyrok Sądu Apelacyjnego w Poznaniu z dnia 18 kwietnia 2013 r., III AUa 1396/12, LEX nr 1322556.

11 Wyrok Sądu Apelacyjnego w Szczecinie z dnia 13 października 2011 r., III AUa 327/11, LEX nr 1381297.

${ }_{12}$ Wyrok Sądu Apelacyjnego w Białymstoku z dnia 21 stycznia 2014 r., III AUa 813/13, LEX nr 1422316.

${ }^{13} \mathrm{~Np}$. pełnienie funkcji trenera sportowego.

${ }^{14}$ Umowy z członkami zarządów spółek kapitałowych - zob. wyrok Sądu Apelacyjnego w Łodzi z dnia 11 marca 2014 r., III AUa 1048/13, LEX nr 1461066.

15 R. Longchamps de Berier, Zobowiazania, Poznań 1948, s. 557. 
postrzegany przez wielu innych autorów, jak i krytykowany w doktrynie prawa cywilnego ${ }^{16}$. Przeciwnicy tego ujęcia przyjmowali, że rezultat dzieła powinien być ucieleśniony, a więc znajdować wyraz w przedmiotach materialnych. W najnowszych wypowiedziach przyznaje się więc, że problem uznania za przedmiot dzieła rezultatów niematerialnych nieucieleśnionych jest kontrowersyjny. Zdaje się jednak dominować pogląd, że rezultaty takie nie mogą zostać uznane za przedmioty umowy o dzieło, gdyż:

1) dzieło musi mieć przymiot samoistności,

2) elementem regulacji umowy o dzieło jest odpowiedzialność przyjmującego zamówienie za wady dzieła, a ponadto najczęściej nie wchodzi w rachubę ich określenie z góry ${ }^{17}$.

Bardzo podobnie twierdzi się, że kwalifikacja prawna rezultatów niematerialnych, które nie zostały utrwalone materialnie (np. inscenizacja teatralna, recytacja poezji, wykonanie utworu muzycznego) co do zasady wyklucza uznanie takich rezultatów za dzieło w ujęciu art. 627 k.c. ze względu na brak cechy samoistności i możliwości oceny według kryteriów właściwych dla wad dzieła ${ }^{18}$.

Jeszcze na gruncie przepisów kodeksu zobowiązań wypowiedział się na ten temat także Sąd Najwyższy. W wyroku z dnia 13 marca 1967 r., I CR $500 / 66^{19}$, stwierdzono, że umowa, w której strona zobowiązuje się do wykonania określonej produkcji artystycznej za wynagrodzeniem, ma cechy umowy o dzieło, a nie umowy zlecenia. Treścią bowiem zobowiązania wykonawcy nie jest samo podjęcie i wykonywanie określonych czynności, lecz ustalony w umowie ich wynik w postaci wystawienia widowiska odpowiadającego pewnym ustalonym z góry warunkom. Ponadto Sąd Najwyższy przyjął, że powyższego charakteru prawnego nie traci umowa wskutek tego, że przedmiotem zobowiązania jest wystawienie nie jednego, lecz większej liczby widowisk. Mimo bowiem zmiany ilościowej treść zobowiązania nie ulega zmianie. Istotne jest również, że w konsekwencji w wyroku tym uznano, że rezultat obejmuje m.in. „poziom wykonania" widowiska, który podlega weryfikacji sądowej. W razie zaś ustalenia wadliwego wykonania dzieła możliwe byłoby obniżenie wynagrodzenia na podstawie art. $486 \S 1 \mathrm{k.z}$.

Jednak w nowszych orzeczeniach Sąd Najwyższy zdaje się prezentować pogląd przeciwny. W wyroku z dnia 21 marca 2013 r., III CSK 216/1220,

${ }^{16}$ Zob. L. Ogiegło, Usługi jako przedmiot stosunków obligacyjnych, Uniwersytet Śląski, Katowice 1989, s. 194 i nast. oraz powołana tam literatura.

17 A. Brzozowski, w: Kodeks cywilny, t. II, red. K. Pietrzykowski, C.H.Beck, Warszawa 2013, s. 326-327.

18 P. Drapała, w: Kodeks cywilny. Komentarz, t. III, cz. 2, red. J. Gudowski, LexisNexis, Warszawa 2013.

${ }^{19}$ OSNC 1968, nr 1, poz. 5.

${ }^{20}$ LEX nr 1324298. 
jednoznacznie stwierdzono, że na podstawie umowy o dzieło w rozumieniu art. 627 k.c. przyjmujący zamówienie zobowiązuje się do wykonania określonego dzieła, którego efektem końcowym jest pewien rezultat $\mathrm{w}$ postaci materialnej lub niematerialnej ucieleśniony $\mathrm{w}$ rzeczy. Na tej podstawie usługi w rodzaju szkolenia personelu czy konsultacji, jako nie generujące żadnego ucieleśnionego rezultatu w jakiejkolwiek postaci, zostały zakwalifikowane jako czynności starannego działania. Także w wyroku z dnia 27 marca 2013 r., I CSK 403/1221, Sąd Najwyższy równie stanowczo stwierdził, że umowa o dzieło, będąca umową rezultatu, różni się od umów starannego działania koniecznością osiągnięcia oznaczonego rezultatu ludzkiej pracy, który musi mieć charakter samoistny i musi być ucieleśniony, a więc przybrać określoną postać w świecie zjawisk zewnętrznych. Rezultat ten musi być przy tym sprawdzalny, czyli zdatny do poddania sprawdzianowi na istnienie wad fizycznych.

Szczególna uwaga zostanie poświęcona problemowi kwalifikacji umów w przedmiocie prowadzenia wykładów. Wynika to z profesji Szanownego Jubilata, a więc i środowiska akademickiego, jak i z licznych w ostatnim czasie przypadków rozstrzygania dotyczących tego sporów przez Sąd Najwyższy.

386 Wstępnie należy zauważyć, że w uzasadnieniach wyroków sądowych pojawia się pojęcie wykładu "akademickiego" czy „naukowego”, które nie występuje w tekście przepisów. Zdaniem Sądu Najwyższego wykład taki musi mieć charakter niestandardowy, niepowtarzalny oraz wypełniać kryteria twórczego indywidualnego dzieła naukowego ${ }^{22}$. Opierając się na tym kryterium Sąd Najwyższy wielokrotnie orzekał o charakterze zawartej umowy cywilnoprawnej rozstrzygając, że niesprecyzowane wykłady z danej dziedziny wiedzy nie stanowią utworu o indywidualnym charakterze $\mathrm{w}$ rozumieniu prawa autorskiego, ale sa przekazywaniem odbiorcom wykładu wiedzy z danej dyscypliny ${ }^{23}$. Także $w$ wyroku z dnia 14 listopada 2013 r., II UK 115/1324, Sąd Najwyższy uznał, że nie stanowi umowy o dzieło umowa o przeprowadzenie cyklu wykładów (zajęć dydaktycznych), w której przyjmujący zamówienie zobowiązał się jedynie do starannego przeprowadzenia zajęć „z zakresu multimediów”. Również w wyroku z dnia 3 października 2013 r., II UK 103/1325, Sąd Najwyższy przyjął, że umowa o przeprowadzenie cyklu bliżej niesprecyzo-

${ }^{21}$ LEX nr 1341643.

${ }^{22}$ Tak Sąd Najwyższy w wyroku z dnia 27 sierpnia 2013 r., II UK 26/13, MPP 2014, nr 1, s. 2.

${ }^{23}$ Wyrok Sądu Najwyższego z dnia 6 sierpnia 2014 r., II UK 566/13, LEX nr 1500668.

${ }^{24}$ LEX nr 1396411.

25 OSNP 2014, nr 9, poz. 134. 
wanych wykładów z określonej dziedziny wiedzy, których tematy zostały pozostawione do uznania wykładowcy, nie jest umową o dzieło w rozumieniu art. 627 k.c. Bardzo podobne stanowisko zostało wyrażone przez Sąd Najwyższy w wyroku z dnia 4 lipca 2013 r., II UK 402/12²6. Stwierdzono w nim, że przeprowadzeniu cyklu wykładów nie towarzyszy przyjęcie odpowiedzialności za ich rezultat. Takiemu zobowiązaniu nie można więc przypisać cech umowy o dzieło. Konsekwentnie Sąd Najwyższy przyjmuje, że ze względu na brak rezultatu nie jest umową o dzieło umowa o przeprowadzenie szkolenia kierowców ${ }^{27}$. W orzeczeniach tych pojawiają się dwa różne kryteria kwalifikacyjne. Konieczność określenia przedmiotu wykładu nie budzi wątpliwości. Natomiast powiązanie kwalifikacji stricte cywilnoprawnej z kryterium wziętym z prawa autorskiego już na wstępie wydaje się co najmniej wątpliwe.

Przechodząc do próby oceny prawnej wykładu należy stwierdzić, że we wcześniejszej literaturze przyjmowano, że umowa o prowadzenie wykładu lub wykładów poza stosunkiem pracy jest umową o świadczenie usług $\mathrm{z}$ art. 750 k.c. ${ }^{28}$

Według Sądu Najwyższego umowa o przeprowadzenie cyklu wykładów z danej dziedziny wiedzy nie jest umową o dzieło. $W$ orzeczeniach dotyczących tego problemu powołano jednak dodatkowe argumenty (kryteria). Wydaje się, że często zasadniczym elementem wykluczającym zakwalifikowanie spornej umowy jako dzieła było to, że strony nie sprecyzowały ściśle problematyki wykładów ${ }^{29}$. Nieco inaczej problem ten został ujęty w wyroku Sądu Najwyższego z dnia 4 lipca 2013 r., II UK 402/1230. Oceniając okoliczności faktyczne sprawy przyjęto bowiem, że poprzez przeprowadzenie wykładów z rachunkowości nie jest możliwe osiągnięcie materialnego rezultatu, gdyż przy tego rodzaju czynnościach nie da się tego zrobić. Bardzo podobnie Sąd Najwyższy ocenił charakter prawny umowy o szkolenie personelu czy o konsultacji. W wyroku z dnia 21 marca 2013 r., III CSK 216/1231, stwierdził, że efektem dzieł jest rezultat $\mathrm{w}$ postaci materialnej lub niematerialnej ucieleśniony w rzeczy. Usługi szkoleniowe nie generują żadnego rezultatu ucieleśnionego w jakiejkolwiek postaci i muszą być kwalifikowane jako czynności starannego działania. W wyrokach tych Sąd Najwyższy

${ }^{26}$ LEX nr 1350308.
${ }_{27}$ Wyrok Sądu Najwyższego z dnia 13 czerwca 2012 r., II UK 308/11, LEX nr 1235841.
28 Tak J. Szczerski, w: Kodeks cywilny. Komentarz, t. II, Warszawa 1972, s. 1377.
${ }_{2}$ Tak Sąd Najwyższy w wyrokach z dnia 3 października 2013 r., II UK 103/13, OSNP 2014, nr 9, poz. 134, z dnia 6 sierpnia 2014 r., II UK 566/13, LEX nr 1500668 czy z dnia 14 listopada 2013 r., II UK 115/13, LEX nr 1396411.

${ }^{30}$ LEX nr 1350308.

${ }^{31}$ LEX nr 1324298. 
rozstrzygał problem kwalifikacji spornych umów w sposób negatywny, to znaczy przyjmował, że nie są to umowy o dzieło. W uzasadnieniach tych orzeczeń odwoływano się do poglądów doktryny i wcześniejszych orzeczeń w kwestii rezultatów umowy o dzieło i konieczności ich ucieleśnienia. Trudno jednak jednoznacznie stwierdzić, jakie stanowisko zostało przyjęte przez Sąd Najwyższy. Ponadto w orzeczeniach tych pojawia się wątek dotyczący kwalifikacji dzieła w rozumieniu przepisów prawa autorskiego.

Przykładem wykorzystania kryterium twórczego dla kwalifikacji umowy o dzieło jest wyrok Sądu Najwyższego z dnia 4 czerwca 2014 r., II UK 548/1332. Należy w tym miejscu wyraźnie zaznaczyć, że rozstrzygany w sprawie spór dotyczył kwalifikacji prawnej umowy, a nie jej autorskiego charakteru. Sąd Najwyższy przyjął, że sporne umowy (wykłady w szkole wyższej) były umowami zlecenia lub innymi umowami nienazwanymi o świadczenie usług, regulowanymi w art. 750 k.c. z uwagi na ciągłość usługi i sposób wynagradzania. W uzasadnieniu omawianego wyroku akceptująco przytoczono poglądy doktryny przyjmujące, że utwór o charakterze nieucieleśnionym nie może stanowić przedmiotu umowy o dzieło i orzecznictwa, że czynność prowadzenia wykładu nigdy nie odrywa się od wykładowcy i trwa tak długo, jak wygłaszanie wykładu, po którego zakończeniu wygasa, nie pozostawiając ucieleśnionego rezultatu. W wyroku tym Sąd Najwyższy stwierdził jednak także wprost, że możliwa jest umowa o dzieło nieobjęta obowiązkiem ubezpieczenia społecznego, której przedmiotem jest wygłoszenie wykładu, pod warunkiem jednak, że wykładowi można przypisać cechy utworu. Warunki te spełnia natomiast tylko wykład naukowy (cykl wykładów) o charakterze niestandardowym, niepowtarzalnym, wypełniający kryteria twórczego $\mathrm{i}$ indywidualnego dzieła naukowego.

Pogląd powyższy jest co najmniej wątpliwy. Po pierwsze Sąd Najwyższy przyjmuje, że jeżeli przedmiotem umowy jest utwór naukowy chroniony prawem autorskim, to jego zamówieniu tradycyjnie odpowiada umowa o dzieło. Wynikałoby więc z tego, że autorski charakter utworu przesądza o cywilnoprawnej kwalifikacji umowy. Założenie to jest oczywiście błędne. Prawo autorskie nie reguluje bowiem rodzaju umów przewidzianych dla zamówienia utworu. W tej sytuacji kwalifikacja zawartej umowy musi opierać się na przepisach kodeksu cywilnego. Należałoby więc raczej przyjąć, że autorski charakter przedmiotu umowy w ogóle nie ma wpływu na rozróżnienie umów o dzieło od pozostałych umów cy-

${ }^{32}$ LEX nr 1496287, identycznie Sąd Najwyższy w wyroku z dnia 4 czerwca 2014 r., II UK 420/13, LEX nr 1480060. 
wilnoprawnych. Bezprzedmiotowe jest także odwoływanie się do problematyki podatkowej - kosztów uzyskania przychodu. Koszty te nie są bowiem uzależnione od rodzaju zawartej umowy cywilnoprawnej, a jedynie od autorskiego charakteru przychodu ${ }^{33}$. Bez znaczenia powinna pozostać też praktyka minionych lat wynikająca, między innymi, ze stanowiska Ministerstwa Kultury i Sztuki. W piśmie z dnia 10 lipca 1995 r. ${ }^{34}$ stwierdzono, że umowa o dzieło jest najwłaściwszą umową do umawiania się $\mathrm{z}$ twórcami o stworzenie utworu. Jest to bowiem umowa rezultatu, a prawo autorskie, chroniąc konkretny „utwór”, a nie twórczość w ogóle, preferuje tę właśnie formę umowy do umawiania się z twórcami o stworzenie utworu (dzieła).

W doktrynie prezentowane jest stanowisko całkowicie odmienne. Twierdzi się bowiem, że umowa o dzieło nie przystaje do realiów wynikających z twórczości ${ }^{35}$. Autor uzasadnia swój pogląd tym, że na gruncie prawa autorskiego dokładne określenie rezultatu nie wydaje się ani możliwe, ani potrzebne oraz faktem, że twórca odpowiada jedynie za starania osiągnięcia rezultatu $\mathrm{w}$ postaci utworu. Ostatecznie według wspomnianego autora umowy prawa autorskiego są umowami starannego działania, a nie rezultatu i to niezależnie od tego, czy utwór zostanie zapisany na nośniku.

Pogląd powyższy nie jest oczywisty, a jego ocena zależy od przyjęcia określenia rezultatu dzieła o charakterze niematerialnym. W omawianym wyroku Sąd Najwyższy powołał się w tej kwestii jedynie na wyrok Sądu Najwyższego z dnia 30 maja 2001 r., I PKN 429/00³. Rzeczywiście $\mathrm{w}$ uzasadnieniu tego orzeczenia zawarte jest jedno zdanie odnoszące się do kwalifikacji wykładu jako dzieła nieucieleśnionego. Jednak przedmiotem sporu była kwalifikacja umowy jako umowy o pracę. Ostatecznie zaś w wyroku owym stwierdzono, że zatrudnienie nauczyciela w niepublicznej szkole artystycznej może być wykonywane na podstawie umowy cywilnoprawnej.

Podsumowując należy stwierdzić, że w komentowanym wyroku Sąd Najwyższy trafnie rozstrzygnął spór. Jednak uzasadnienie stanowiska w sprawie możliwości kwalifikowania wykładu pozostawia wiele niedosytu.

${ }^{33}$ Tak samo wygląda problem na gruncie przepisu art. 104 ust. 5 ustawy emerytalnej, który przewiduje wyjątek dla honorariów autorskich bez względu na podstawę ich uzyskania. Tak też Sąd najwyższy w wyroku z dnia 3 kwietnia 2013 r., II UK 213/12, OSNP 2014, nr 1, poz. 13.

${ }^{34}$ LEX nr 2969.

35 P. Ślęzak, Stosowanie przepisów kodeksu cywilnego o umowie sprzedaży, zlecenia i o dzieło, [w:] Umowy w zakresie wspótczesnych sztuk wizualnych, LEX 2012 i cytowana tam literatura.

${ }^{36}$ OSPN 2003, nr 7, poz. 174. 


\section{Wnioski}

Na postawie wyżej przeprowadzonych rozważań jedynie jeden wniosek jest bezsporny. Otóż zarówno w doktrynie, jak i orzecznictwie Sądu Najwyższego prezentowane są sprzeczne stanowiska. Wynika to z tego, że granice pomiędzy umową o dzieło i umową zlecenia są niezwykle płynne, a więc trudne do jednoznacznego określenia. Zawierane umowy często mają elementy charakterystyczne zarówno dla dzieła, jak i zlecenia. Przykładem mogą być umowy dotyczące kompletowania (klejenia) akt i wprowadzenia ich do systemu komputerowego ${ }^{37}$.

Zasadniczy problem dotyczy pojmowania rezultatu „dzieła” o charakterze niematerialnym, który nie jest ucieleśniony w rzeczy. Ograniczając wnioski do umowy, której przedmiotem jest wygłoszenie wykładu, należy stwierdzić, że pożądane byłoby ujednolicenie stanowiska Sądu Najwyższego w tym zakresie. Trzeba przy tym zauważyć, że całokształt okoliczności faktycznych rozstrzyganych spraw jest niezmiernie zróżnicowany. Często więc podstawą rozstrzygnięć sądowych charakteru spornej umowy jest nie tylko jej przedmiot, ale i inne kryteria. Oprócz określenia rezultatu dzieła brane są więc także pod uwagę takie elementy, jak np. wola stron, przeważające elementy rodzajowe, treść umowy, moż-

390 liwość poddania rezultatu sprawdzianowi na istnienie wad fizycznych, cykliczność wykonywanych czynności (jednorazowość), samodzielność w wykonaniu czy ryzyko rezultatu.

Ze względu na dużą różnorodność zawieranych umów o świadczenie usług nie wydaje się, by było możliwe stworzenie katalogu kryteriów, który pozwoliłby na jednoznaczne rozstrzygnięcie wątpliwości kwalifikacyjnych umów cywilnoprawnych o świadczenie usług. Podobnie zresztą jak w przypadku rozgraniczenia umów cywilnoprawnych od umowy o pracę.

Wracając do problemu zasadniczego należy, moim zdaniem, opowiedzieć się za tym, że wykład, nawet o charakterze akademicko-naukowym, powinien być kwalifikowany jako umowa starannego działania. Przemawia za tym okoliczność, że rezultatu wykładu nie da się jednoznacznie określić $w$ umowie. Nie przekonują też argumenty przeciwne, o rezultacie w postaci wrażeń widza (słuchacza), samym rezultacie w postaci wygłoszenia wykładu czy autorskim charakterze przedmiotu umowy. Rezultat umowy powinien bowiem zależeć od samego zobowiązanego. Natomiast jeżeli osiągnięcie rezultatu zależy od cech, zachowania i właściwości czy wrażeń (doznań) zamawiającego, to umowy takiej nie można kwalifikować jako umowy o dzieło ${ }^{38}$. Sąd Najwyższy wielokrotnie akcentował rów-

${ }_{37}$ Zob. postanowienie Sądu Najwyższego z dnia 2 grudnia II UK 245/14, niep.

${ }_{38}$ M. Rafacz-Krzyżanowska, Wpływ zatrudnienia na uprawnienia emerytalno-rentowe, „Praca i Zabezpieczenie Społeczne” 1996, nr 1, s. 43. 
nież, że rezultatem nieucieleśnionym w rzeczy nie może być czynność, a jedynie wynik tej czynności ${ }^{39}$. Ponadto należy tu zauważyć, że niektóre przepisy kodeksu cywilnego o dziele w żaden sposób nie przystają do jakichkolwiek rezultatów niematerialnych wykładu. Chodzi tu o „oddanie dzieła" i "oddanie dzieła częściami” (art. 642 k.c.), "odebranie dzieła” (art. 643 k.c.), odstąpienie „dopóki dzieło nie zostało ukończone” (art. 643 k.c.), przedawnienie roszczeń „od dnia oddania dzieła” (art. 646 k.c.), czy wreszcie rękojmia za wady dzieła (art. 638 k.c.). Przepisy te niewątpliwie mogą być odnoszone jedynie do rezultatu dzieła w formie ucieleśnionej. Rezultat wykładu nie ma więc samoistnego bytu po jego zakończeniu. Wydaje się, że charakter prawny wykładu nie zmienia się nawet wtedy, gdy zostanie on zapisany na nośniku. Wyjątkiem byłaby umowa zawarta w celu zapisania wykładu na nośniku, który z założenia miałby stać się przedmiotem dalszego obrotu. Tak samo należałoby ocenić nagranie płyty z koncertem czy innego rodzaju widowiskiem scenicznym.

Należy także mieć na uwadze, że przyjęcie stanowiska przeciwnego spowodowałoby konieczność rozważenia kwalifikowania umów o szkolenia, itp. jako umów o dzieło. Nie powinno bowiem ulegać wątpliwości, że dziełem mogą być także umowy, które nie mają charakteru autorskiego. $Z$ drugiej strony, jeżeli przedmiotem umowy o dzieło ma być utwór $\mathrm{w}$ rozumieniu prawa autorskiego, to przedmiot umowy powinien być tak określony, aby obowiązkiem przyjmującego zamówienie było dostarczenie zamawiającemu dzieła będącego rezultatem działalności twórczej, o indywidualnym charakterze, ustalonego w skonkretyzowanej przez strony postaci. $W$ razie zawarcia takiej umowy do oceny praw i obowiązków stron mają zastosowanie przepisy kodeksu cywilnego, a w zakresie, $\mathrm{w}$ którym dzieło jest utworem, przepisy prawa autorskiego ${ }^{40}$.

Mając na uwadze to, że spór dotyczący nieucieleśnionego rezultatu umowy toczył się $\mathrm{w}$ doktrynie prawa cywilnego jeszcze na gruncie przepisów kodeksu zobowiązań, trudno jest oczekiwać, by został niebawem jednoznacznie rozstrzygnięty. W tej sytuacji niezmiernie istotne jest ujednolicenie stanowiska Sądu Najwyższego. W chwili obecnej można bowiem bez większego problemu uzasadnić dwa sprzeczne ze sobą stanowiska odpowiednio dobierając zarówno stosowne poglądy doktryny, jak i orzeczenia Sądu Najwyższego.

Na zakończenie można stwierdzić, że rozwiązaniem problemu rozróżnienia umowy o dzieło od umowy zlecenia w aspekcie ubezpieczeniowym byłoby ich jednakowe potraktowanie w zakresie obowiązku opłacania składek. Ponieważ w chwili obecnej nierealne jest postulowanie

${ }^{39}$ Np. w wyroku z dnia 4 lipca 2013 r., II UK 402/12, LEX nr 1350308.

${ }^{40}$ Wyrok Sądu Najwyższego z dnia 18 czerwca 2003 r., II CKN 269/01, OSNC 2004, nr 9, poz. 142. 
zrezygnowania z „oskładkowania” umów zlecenia do rozważenia pozostałaby możliwość objęcia tym obowiązkiem umów o dzieło. Wykluczyłoby to możliwości obchodzenia obowiązku ubezpieczenia społecznego i usunęło problemy związane $z$ odróżnieniem poszczególnych umów. Problemy związane z odróżnieniem umowy o dzieło wyraźnie pokazują podobieństwa tej umowy z umową o charakterze zlecenia. $Z$ tego również powodu zasadne jest pytanie o celowość tak znacznego zróżnicowania tych umów w prawie ubezpieczeń społecznych. Problem ten wymagałby odrębnego omówienia na gruncie regulacji prawa ubezpieczeń społecznych.

\section{Bibliografia}

Brzozowski A., Kodeks cywilny, t. II, red. K. Pietrzykowski, C.H.Beck, Warszawa 2013.

Drapała P., Kodeks cywilny. Komentarz, t. III, cz. 2, red. J. Gudowski, LexisNexis, Warszawa 2013.

Gersdorf M., Prawo zatrudnienia, Warszawa 2013.

Gersdorf M., Umowa o prace. Umowa o dzieło. Umowa zlecenia, Warszawa 1993.

Longchamps de Berier R., Zobowiazania, Poznań 1948.

Musiała A., Zatrudnienie niepracownicze, Difin, Warszawa 2011.

392 Ogiegło L., Ustugi jako przedmiot stosunków obligacyjnych, Uniwersytet Śląski, Katowice 1989.

Rafacz-Krzyżanowska M., Wptyw zatrudnienia na uprawnienia emerytalno-rentowe, „Praca

i Zabezpieczenie Społeczne" 1996, nr 1.

Siuda W., Istota i zakres umowy o dzieło, Poznań 1964.

Szczerski J., Kodeks cywilny. Komentarz, Warszawa 1972.

Ślęzak P., Stosowanie przepisów kodeksu cywilnego o umowie sprzedaży, zlecenia i o dzieło,

[w:] Umowy w zakresie wspótczesnych sztuk wizualnych, LEX 2012.

\section{Problems of the Legal Qualification of the Specific Task Contract}

\section{Summary}

Problems associated with performing work under civil law contracts have gained significant importance after the change in the socio-economical system. The reason behind it was that the employers were seeking to minimize costs, which resulted in concluding civil law contracts, rather than employment contracts. Currently, as there is no obligation to make social security contributions, the most popular form of civil law agreements is a contract for specific work. Despite the fact that the provisions concerning contracts to perform specific work have not changed for decades, to date fundamental problems concerning distinguishing contracts to perform specific work from other service related employment contracts have not been resolved. Also, judicial decisions highlight the difficulties in establishing the true nature of employment contracts. The article elaborates on fundamental problems with regard to the legal qualification of contracts to perform specific work, which forms the grounds for de lege ferenda conclusions. 